\title{
Against the Grain
}

Volume 18 | Issue 6

Article 16

December 2006

\section{ATG Interviews Hazel Woodward}

Katina Strauch

Against the Grain, kstrauch@comcast.net

Follow this and additional works at: https://docs.lib.purdue.edu/atg

Part of the Library and Information Science Commons

\section{Recommended Citation}

Strauch, Katina (2006) "ATG Interviews Hazel Woodward," Against the Grain: Vol. 18: Iss. 6, Article 16. DOI: https://doi.org/10.7771/2380-176X.4693

This document has been made available through Purdue e-Pubs, a service of the Purdue University Libraries. Please contact epubs@purdue.edu for additional information. 
by Katina Strauch (Editor, Against the Grain) <kstrauch@comcast.net>

ATG: Hazel, you were appointed university librarian at Cranfield University and director of Cranfield University Press in October 1998. Tell us about Cranfield University. Number of students and faculty? Courses? Age of school? Etc.

Cranfield University is the UK's only postgraduate university (comparable to $\mathrm{Cal}$ Tech in the US). It grew out of Cranfield College of Aeronautics which was founded in 1946 by a government that recognised the importance of research and development in aviation following the war. The University has three campuses: one is at Cranfield near Bedford and Milton Keynes; the second is at Silsoe - 15 miles from Cranfield; the third is the Defence College of Management Technology at Shrivenham near Swindon. The average age of the 3,500 students is 29 and the main subjects are aeronautics, engineering, manufacturing, management, defence, health and bioscience. The Library and Information Service comprises five libraries one at Silsoe and Shrivenham and three on the Cranfield campus including the Sir Norman Foster designed Kings Norton Library, the Management Information Resource Centre and the Knowledge Interchange for the executive client of the School of Management.

ATG: Tell us about yourself and your library background. When and where did you get your PhD.?

My library qualifications were obtained at Leeds Library School - a thriving school at the time - and a wonderful city to study in. My first job was at Trinity and All Saints College near Leeds and I stayed there for almost two years. I was lured away by the post of Deputy Librarian at Loughborough College of Education which was soon to become part of Loughborough University. Unbeknown to me at the time I was to spend a fair chunk of my career at Loughborough University so it was lucky that I had a series of really interesting jobs over the years. I guess the main reason for not moving (apart from inertia and enjoying what I was doing!) was to do with not wishing to uproot my family - husband and two sons. As said sons are now 21 and 23 respectively it's no longer an issue. Whilst working in the library at Loughborough I was fortunate to become involved with an electronic journals research group in the Department of Information Science which was actually housed on the third floor of the library (a sort of "teaching library" concept). Professor Jack Meadows led that group and since meeting with Jack all those years ago he really has been a mentor to me throughout my subsequent career. It was he who encouraged me to do my $\mathrm{PhD}$ in the first place and cajoled and supported me when I fell behind in my writing up. My final post at Loughborough was Head of Electronic Infor- mation which was really exciting because, as we all know, things really started hotting up in this area towards the end of the 1990s.

ATG: What sorts of changes have taken place in the University since you arrived? What are the five or ten most important issues that you have had to deal with?

I took up the post of University Librarian and Director of Cranfield University Press in 1998. This did involve the family moving to Bedford but the boys were that much older and preparing for University and my husband (Fytton Rowland who still works at Loughborough) was happy to commute by train. My first strategic decision was to develop the digital library strategy and ensure that it was bought into by the senior management of the University. This has stood us in very good stead over the last few years.

ATG: Tell us about your acquisitions and collection development policies. Are you still buying/funding the purchase of print materials? Is there a need for collection development in the new virtual library?

When I arrived in Cranfield the library subscribed to some 3,000 printed journals. We now provide access to well over 8,000 electronic journals and the number of printed journals is less than 100 . We have also developed our eBook holdings and subscribe to a number of packages and services for eBooks. The next challenge is to see what we can do about acquiring e-textbooks. I hope that I can influence this at a national level as one of the external roles I have at the moment is Chair of the Joint Information Systems Committee (JISC) eBooks Working Group. As is the case in most libraries we constantly evaluate the resources that we take to ensure that we are providing the most appropriate sources. We have been fortunate that, on a number of occasions, we have been able to negotiate additional funding to acquire new and important resources e.g., Taylor \& Francis e-journals and Scopus. To manage our growing range of e-resources we have recently purchased an ERM system (Verde) which we are in the process of populating with data.

ATG: What sort of services do y'all offer to your students and faculty? Tell us about your students and faculty.

We are also very proud of the fact that Cranfield QuePrints (our institutional repository) is one the largest in the UK and now contains over 800 full text documents created by Cranfield research staff, including published articles, working papers, reports and theses.

Because of our specialist nature and the fact that we have relatively small numbers of staff and students a key feature of the library service is customer service. Our customers say that what they most appreciate about us is the personal service they receive and the individual support that is available to them, whether or not they are on or off campus. Customers are at the heart of our service and the physical and virtual environments that we provide are a reflection of that. We took part in the LibQUAL customer satisfaction surveys in 2005 and 2003. I'm very happy to report that Cranfield scored well above the national average in all aspects of the service and in several key measures exceeded expectation of respondents.

A key element of library strategy has been to maintain a very active research profile. This has been an important feature of the library's work stretching all the way back to the late 1950s. Current projects include: AERADE - the Internet portal for aerospace and defence engineering now partly funded by the JISC. The popularity of the AERADE continues to grow with the service receiving an average of 126,000 page requests per month last year, with customers from nearly 190 countries. ETHOS is another JISC funded project where Cranfield is project partner. THOS (Electronic Theses Online Service) has been running from early 2005. As well as looking at the technical aspects of setting up a central host system, the project will also be investigating appropriate business models and issues concerning IP and permissions procedure.

ATG: Tell us about Cranfield University Press. One of your first moves was to purchase new digital equipment. How many items do you publish and in what format(s)?

My other area of responsibility is the University Press and over the last few years we have gradually upgraded much of the equipment in the Press so that we now run a range of state-of-the art digital services. Much of the work undertaken by the Press is printing work in support of the universities business but we do have a modest publishing output. However, I remain to be convinced that small university presses have a serious future in the publishing industry of today.

ATG: You are the editor of Serials. How old is the journal? Can you fill us in about it?

On aspect of my wider work within the information industry, and one which I really enjoy, is being joint editor of the journal Serials along with Helen Henderson. Serials is published by the UK Serials Group and it started way back in 1987 . I am very proud that Helen and I have really developed the journals since we took over in 2001. We have appointed a truly international editorial board, begun accepting peer reviewed papers, set up the highly successful Serials E-News which is delivered to all members on a fortnightly basis,

continued on page 48 
Interview - Hazel Woodward from page 46

and digitised back files of the journal - making them freely available via MetaPress.

ATG: Tell us about the UK library and publishing markets? Are eBooks taking off in the UK?

You ask about the UK library market and the UK publishing industry. I think that UK academic libraries, on the whole, are in good shape. Of course we don't have huge budget increases but on the other hand we have introduced a level of stability and many have got out of the cycle of annual cancellations which was so depressing. The main reason for that has been the national e-journal negotiation undertaken by JISC via the NESLi2 initiative and other national and regionally negotiated deals for e-databases and eBooks. As far as eBooks are concerned, take-up has been slow and this is probably due to the fact that publishers have struggled to find appropriate business models which appeal to libraries. That is beginning to change which is encouraging.

We also have a vibrant research and development environment - once again funded by the government via JISC. For example, a $£ 10$ million call has gone out recently for digitisation projects for important and unique research collections in UK libraries.

ATG: Will we have libraries in the future? What predictions would you make about scholarly publishing/communication over the next, say, ten years?

I don't think I have anything particularly profound to say about the future except that libraries and publishers will almost certainly find themselves responding more and more to the activities of information giants such as Google, Microsoft and Yahoo!. Libraries will increasingly need to tailor their services to their students and staff to provide focused, individual and relevant support for their learning, teaching and research. Peer review - possibly not in its traditional guide - will continue to be of paramount importance in a research world where quality is crucial.

\section{CONTACT INFORMATION}

Dr. Hazel Woodward

University Librarian \&

Director of Cranfield University Press

Kings Norton Library

Cranfield University

Cranfield, Bedfordshire, MK43 0AL

Phone: $+44(0) 1234754446$

Fax: $+44(0) 1234752391$

<h.woodward@cranfield.ac.uk>

\section{$\mathbb{F}_{\text {rom }}$ the Reference Desk}

by Tom Gilson (Head, Reference Services, Addlestone Library, College of Charleston, 66 George Street, Charleston, SC 29401; Phone: 843-953-8014; Fax: 843-953-8019)<gilsont@cofc.edu>

$\mathrm{T}$ The struggle for civil liberties is at the core of America's beginning and runs throughout our history. Needless to say, it has been a complex process with numerous contradictions and inconsistencies. The search for religious freedom, the right to privacy, and due process played out in tandem with the institution of slavery, immigration restrictions and blacklists. This complexity is only compounded by our age of "high-tech terror" pitting civil liberties against society's need to be protected.

Helping to sort through these vital issues is a recent encyclopedia published by Routledge. Edited by respected scholar Paul Finkelman, the Encyclopedia of American Civil Liberties (2006, 0415943426, \$475) contains 1,423 entries that vary in length from 250 to 6,000 words. Articles discuss major personalities and influential laws and legal cases, as well as treating broader themes, issues, and events. The biographical entries run the gamut from historic figures like James Madison, Frederick Douglass, and Margaret Sanger to contemporaries ranging from Janet Reno to John Ashcroft to Larry Flynt. Numerous legal cases and individual laws are presented providing their context, relevance and resulting impacts. Larger themes and concepts from affirmative action to rule of law and from victims' rights to theories of privacy are covered as are historical overviews on topics as diverse as the right to bear arms, judicial review, segregation, and sentencing guidelines.

The articles are well written and grounded in historical and legal precedence with the overall treatment comprehensive, scholarly and attuned to the importance of the topics being discussed. There is solid use of "see also" references and a thematic list of entries linking related articles. Each entry has a brief bibliography or a list of cases and statutes cited, in most instances, both. The 189-page general index is thorough and makes use of numerous sub-headings to take readers to specific aspects of larger topics.

The Encyclopedia of American Civil Liberties is a timely and important reference. Browsing its contents and reading individual articles reminds us of the pivotal role the struggle for civil liberties has played in our history. Simultaneously, it points to the necessity of keeping this struggle in the forefront of our concerns as we move into the future. This set is a definite purchase for most academic libraries and should receive serious consideration from larger public libraries. High school libraries may want to first consider the Encyclopedia of Civil Liberties in America edited by David Schultz and John R. Vile and published by M. E. Sharpe (2005, 0-7656-8063-7, \$299)

Speaking of works published by M.E.
Sharpe, Social Issues in America: an Encyclopedia $(2006,0765680610, \$ 499)$ is another that is worthy of attention. Edited by the prolific James Ciment, this set consists of eight slender volumes, one of which being an index to the set. More than 2,100 pages have been packed into the set offering coverage of over 150 topical social issues. Although for the most part written by academics, the articles are accessible to general lay readers, high school students and lower division undergraduates. In addition to thorough explanations, each entry has a useful chronology of the issue being discussed. Individual articles are also accompanied by a glossary of terms, two-three primary source documents related to the issue, and a useful list of references and Websites. The topics covered are the type that students gravitate toward when doing social issues research. They are a diverse mix ranging from At-Risk Students to Wilderness Protection; Corporate Crime to Racial Profiling; Identity Theft to Prostitution; and Gay and Lesbian Rights to Terrorism. Attention has also been paid to helping undecided students identify interesting topics. There is a "topic finder" listing topics by broad categories, a unique cross reference index that substitutes for having "see also" references at the end of each entry, and a list of topics covered in each volume.

Social Issues in America: an Encyclopedia has been designed for ease of use and with the intent of being a helpful starting point for exploring high interest issues. That it succeeds so effectively is a compliment to $\mathrm{Mr}$. Ciment and his collaborators. Libraries where social issues are an area of interest or a focus of student research would be well served by considering this set. Those libraries looking for a less expensive, but dated, alternative might consider Macmillan's Social Issues edited by Robert D. Benford (1999, 0-02-865055-7, \$125)

Sage Publications recently released a single volume encyclopedia that will be equally at home on reference or circulating shelves. Edited by Barney Warf, the Encyclopedia of Human Geography (2006, 0761988580, \$150) helps define the parameters of this evolving area of geographic study, as well as offering a rich source of background information for numerous concepts, themes and approaches.

As characterized in this encyclopedia, human geography is more than the geography of place. Human geography relates to the "study of how societies construct places, how humans use the surface of the earth, how social phenomena are distributed spatially, and how we bring space into consciousness." The individual entries in this work provide such linkages in a clear understandable fashion, while at the same time, maintaining their scholarly

continued on page 50 